\title{
The History of medical relations between Switzerland and the USA
}

\author{
By Erwin H.Ackerknecht
}

It is a great honor for me to deliver this year, the first year after Doctor Guggenheim's death, the Markus Guggenheim lecture. I need hardly recall to you that Doctor Markus Guggenheim, born in 1885 and dying last year on November 3, was a very eminent chemist, who mastered with admirable fortitude the tragic sequelae of a laboratory accident. He has together with his wife furthered work in the history of medicine and science in Switzerland in a way, for which we can never be grateful enough to him. Most of you have probaly still personally known Doctor Guggenheim, who assisted very faithfully our annual meetings, and whom to honor this lectureship has been established.

When in a symposium concerning the medical relations of Switzerland to other countries reports are given on the relations of Swiss medicine to German, French, Italian, English and Austrian medicine, the reasons are obvious. But it might be at first sight surprising that the U S A are added to this traditional list of neighbours. This surprise is partly a consequence of outdated technological and geographical thought. Actually, through the airplane, New York is as close to Zurich as by railroad are Hamburg or Paris. We should become conscious of this new situation. But partly doubts remain legitimate. Have the relations between American and Swiss medicine really been so weighty and so important as to justify such a procedure? They have been weighty and important, but if we have chosen to deal with the subject today, it actually has not been done so much on account of the past, than on account of the present and the future. In medicine, and even in medical history, our traditional neighbours orient themselves today a good deal towards the United States.

This is perfectly normal. But it seems then somewhat paradoxical to acquire US ideas or techniques secondhand from our traditional neighbours instead of going directly to the sources. To a large extent this is already done in medicine in our country, and even in medical history this development has not been absent. But we might do even better in this respect.

Medical activities of the Swiss in the USA can be traced back to the 17th century. Henry Zimmermann, born in 1673 in Wattenwil, came to Germantown in 1698 where he became an eminent physician. He died in 
Pennsylvania in 1749. As he changed his name to Carpenter it has been largely forgotten that the Pennsylvanian medical dynasty, which still existed in the 20th century by the name of Carpenter is of Swiss origin. A Dr. Benjamin Musser from Bern came supposedly with Penn to the Western hemisphere. In several Swiss publications Swiss ancestry is attributed to the most famous American physician of the 18th century, Benjamin Rush. This is unfortunately a legend. Rush was, as can be easily ascertained, of English quaker linage.

The Swiss contribution in USA medicine came to full fruition in the 19 th century. It took place in the same subdisciplines, for which Switzerland itself became internationally famous during this period: surgery, psychiatry, and basic sciences. Swiss surgery excelled at home through men like Theodor Kocher (1841-1917, Nobelprice 1909), Jacques-Louis Reverdin (1842-1929), L.C.Courvoisier, R.U.Krönlein, A.Socin, César Roux, Heinrich Bircher, or Charles Garré. Swiss psychiatry acquired world fame with Auguste Forel (1848-1931), Paul Dubois, Eugen Bleuler (1857 to 1939), H.Rorschach, or the Binswanger dynasty. In the basic sciences Swiss contributions from Jean-Louis Prévost and Kölliker to J.F. Miescher and A.Yersin are well remembered. A mixture of practicality and spirituality which characterises the Swiss contribution made it congenial to Americans and vice versa.

Swiss surgeons made their way in the US, in spite of the fact that the US had a long and honorable past in surgery. They were particularly influential in the Middle West of the USA. It was this region where so many Swiss and Germans settled during this period. A Carl Schurz e.g. worked first in Wisconsin, Michigan and Missouri. Towards the end of the 19th century the majority of the prominent Chicago surgeons were actually of Swiss origin. We mention here above all Henry BANGa, born 1848 in Liestal, who died 1913 in Chicago. He was the pioneer of antisepsis in the Middle West. His father had been one of the founders of the Kanton Baselland. He himself, in his youth, had been a friend of the wellknown writer J.V.Widmann and the later literary Nobelprice laureate Carl Spitteler. Banga studied in Basel. During the war of 1870 he went with E. Klebs and Socin to Karlsruhe, and collected experience in wound surgery. In 1876 at the age of 28 he settled in Chicago and became one of the prominent surgeons of the Michael Reese Hospital.

Nicholas SenN was born in 1844 in Buchs, St.Gallen. In 1851 his parents settled in Ashford, Wisconsin. He died in 1908 in Chicago. He 
acquired an M. D. in 1868 in Chicago and settled first in Ashford, then in Milwaukee. Then he went to Germany for extensive postgraduate studies and took an M.D. in Munich in 1879. In 1890 he became professor of surgery at Rush College in Chicago. In 1893 he was instrumental in establishing a three year course in this College. In 1897 he was president of the A.M.A. He was the leading military surgeon in Cuba during the Spanish American war and did much to reform the outdated medical establishment of the army. Senn left more than 300 publications and was a man of extraordinary energy and renown. He also gave to the community a very valuable medical library and new medical school buildings. He was always proud of his Swiss roots and visited Switzerland often. Senn founded a surgical dynasty in Chicago.

Another eminent Chicago surgeon of Swiss origin during this period was Albert J. Ochsner, born in 1858 in Baraboo, Wisconsin, who died in 1925 in Chicago. Ochsner's parents had come from Richterswil, Zurich. Ochsner took his M.D. at Rush in 1886 and did postgraduate studies in Europe in 1887-1888. He then moved to Chicago where he became professor of surgery at the University of Illinois Medical College. He was connected with Augustana and St. Mary's Hospital. He was one of the founders of the American College of Surgeons and was the initiator of the fee splitting pledge of this organisation. He was the author of numerous books, and worked especially on peritonitis. Ochsner always emphasized his Swiss ancestry. The Ochsners claim to descend from the family from which came the mother of Paracelsus. Several relations of Albert J.Ochsner were and are still prominent in American surgery.

Another Swiss outstanding in Midwestern surgery was Martin Stamm, born 1847 in Thayngen sH, who died in 1918 in Fremont, Ohio. Martin Stamm graduated in Bern in 1872. His teacher was Theodor Kocher. (It cannot be enough emphasized how tremendous an influence Kocher exercised on American surgeons like Halstead, Cushing etc.!) Stamm emigrated to the US in 1872 and settled in Fremont, Ohio, in 1875. He worked there to his death. He also taught surgery in Cleveland, Ohio. In 1914, during a vacation in Switzerland he became provisory chief of the surgery division of the Inselspital Bern. He was an eminent abdominal surgeon.

Early prominent laryngologists of Swiss origin in the US were CARL Seiler (1849-1905) in Pennsylvania and Anton Ruppaner (1825-1892) in New York. Ruppaner came to the US on the suggestion of his friend 
Agassiz and took an M.D. at Harvard in 1858. In 1866 he settled in New York as a laryngologist.

Adolf Kraemer (1864-1911) took an Ph.D. from Basel in 1892 and an M.D. from Zurich in 1894. After having been an assistant in Basel and Zurich he moved in 1902 to San Diego. He had married an American in 1898. He was an eminent opthalmologist. X. O. WerDer (1857-1919) was born in Cham and came to the US when he was 14 years old. He became one of the outstanding gynaecologists in Pittburg. Prominent Swiss surgeons in the Mid West were also Th. Kocher's pupils Arnold and Gustav Schwyzer, who came to St.Paul, Minnesota, in 1892.

The Swiss influence in US psychiatry was very strong mostly due to the work of Adolf MeYer, of whom one can claim that he has opened a new era in US psychiatry. US psychiatry had so far not developed very much. Adolf Meyer was born in Niederweningen, Zurich in 1866. He graduated in Zurich in 1890. Here ha came very much under the influence of A.Forel. While Forel's school was represented in Europe mainly by Eugen Bleuler, in the US it was mostly Adolf Meyer who spread the message of Forel. After postgraduate studies in Paris, Edinburg and London, Meyer went in 1892 to Chicago as a neuropathologist. From 1895-1902 he worked in Worcester as research director and started there his psycho-biological work. He began there to train students who later on filled numerous chairs of psychiatry in the US. In 1902 he moved to Ward's Island, New York, to the Pathological Institute, which he transformed into the Psychiatric Institute. From 1904-1909 he was professor of psychiatry at Cornell Medical School, from 1910-1940 at Johns Hopkins University in Baltimore. He introduced the Kraepelin classification in the US, but tried to transgress the Kraepelinian system. His notion of psycho-biology opposed the mindbody dichotomy and looked at mental disease as a maladjustment of the total personality. He therefore insisted on a very thorough anamesis. $\mathrm{He}$ combined psychotherapy and work-therapy. He integrated the social worker in psychiatric work. Adolf Meyer was a great educator. He insisted on selfanalysis of his students. Of great value to the community was his founding of the mental hygiene movement together with Clofford Beers in 1908.

Shortly before Meyer August Hoch (1868-1919) of Basel came to the US (1887). He was a student of Oslers in Philadelphia and Baltimore. He too brought Kraepelinian psychiatry to the US. In 1895 he became professor at the Mclean Hospital in Boston. In 1908 he went to Bloomingdale 
Hospital in New York and in 1909 was nominated professor of psychiatry at Cornell. He became there the successor of Adolf Meyer. One of the most eminent disciples of Adolf Meyer was Oskar Diethelm, born in 1897. He took his M.D. in 1923 in Zurich. He worked with Meyer at the Johns Hopkins from 1925-1936 and was professor at Cornell University from 1936 to 1962 .

When thinking of Swiss medical scientists who played a role in the US the first name which comes to mind is of course that of L.Agassiz. We renounce detailed treatment of him here for two reasons: Though he was once for a year professor of anatomy in Charleston, South Caroline, his work has very few, if any relations to medicine. Furthermore 1973 will be an Agassiz year and this Association will deal with him then in greater detail.

An American medical scientist who as late as the last World War has played a decisive role in the US, was CarL Voegtuin, born in 1879 in Zofingen, and dying in 1960 in the Walter Reed Hospital in Washington. Voegtlin was just as outstanding a pharmacologist as he was a toxicologist and oncologist. He studied medicine and chemistry in Basel and then completed his studies in Munich, Geneva, Freiburg and Manchester. 1904 to 1905 he came to Madison, Wisconsin. From there he moved to the Hopkins in Baltimore, where he worked with J.J.Abel, the famous pharmacologist. From 1908-1913 he was professor at the Johns Hopkins University and did outstanding work on the parathyroids and on cancer. In 1913 he became chief of the division of pharmacology in the National Institute of Health and became particularly known for his work on the As receptors. In 1937 he moved up to become chief of the National Cancer Institute in Bethesda, Maryland, and in 1940 he became consultant of the socalled Manhattan Project, that is the atomic bomb project. The fact that a foreign born man, who still remained attached to his country of origin, could fill this important post during the war shows the great scientific and human credit which Voegtlin enjoyed in the US.

A very colourful Swiss contribution to American science was CARL Friedrich Meyer, who was born in Basel in 1884. In 1909 he took his Doctors degree in veterinary medicine in Zurich. He worked from 1908-1910 in Transvaal and then moved to the US, where he was professor at Pennsylvania University from 1910-1913 and from 1913-1950 in the University of California. Meyer is an internationally known bacteriologist. His work on plague was of particular importance in California, where the disease had been imported from Asia and become endemic in the local rodent population. 
Mention should here also be made of Edwin Klebs (1834-1913), the erratic but ingenious bacteriologist, who, though of German origin, spent his best years in Bern, married a Bernese girl, and eventually died there. He very much stimulated bacteriology in the US when through Senn's intervention he became professor of bacteriology at Rush.

It was a Swiss, one of the founders of our society, who really made medical history a functioning scientific discipline in the US and many of you have still known him personally: Henry E. Sigerist, born in Paris in 1891, dying in Pura, Ticino in 1957. Sigerist came to the US in 1932, in order to become Director of the Medical History Institute at the Johns Hopkins University in Baltimore. He remained for 15 years in the US, till his failing health forced him to retire in 1947. Before Sigerist there had been a few able medical historians in the US (e.g F.H.Garrison), but no medical history. Through his extraordinary activity as a speaker and writer, in reorganising the American Association of the History of Medicine and creating a modern medicohistorical journal, the Bulletin, through training a number of disciples, who became professors in other Universities and through winning the sympathies of numerous physicians for medical history, Sigerist changed completely the situation in the US as far as medical history was concerned.

Swiss physicians played, of course, also a certain role in the wars of the US. We hear for instance of F. Staehli, Adolf Steinach, Tissot and other New York Swiss physicians, who during the civil war served with distinction the Union Army. Doctor Henry Wirz fought on the side of the Confederation and became Director of the notorious Andersonville prison. His execution has been later regarded as a judicial error. Even more influential were Swiss physicians in the Spanish American war, which was mostly fought in Cuba. We have already mentioned the activities of N.Senn. Alfred Girard, the uncle of the famous Bern surgeon De Quervain (1841 to 1914) became in the same period a medical general. Voegtlin's role in the second World War has been mentioned above.

It was almost unavoidable that one of the leading homeopaths in the US was of Swiss origin. He was Doctor Henry Detwiler, who was born in 1795 in Langenbrugg, Basel, and who closed his professional career in Pennsylvania in 1887.

Quite a few of the Swiss, who came to the US, like H.Häberlin from Zurich, the Kocher pupil Karl Doepfner, Luzern, or Hermann Mooser practised or worked there only for a few years and then returned. Others 
came only for «Bildungsreisen». The best known of these earlier pilgrims were probably the Bern surgeon Fritz De Quervain (his report dates from 1922) and the psychiatrist August Forel (1900). This habit of going to the US for reasons of information, possibly postgraduate education is a thing of the present, not only the historical past. It has by now become so general amongst people with or without academic ambitions, that it is impossible to give any more data without destroying the structure of this paper. Quite a few of these travellers still remain in the US. It seems significant that the Schweizerisches Medizinisches Jahrbuch for 1970 lists no less than 216 Swiss physicians practising in the US.

We should mention here also the great bacteriologist Max Theilen, though he himself is not Swiss. But his father, the eminent leader of South African medicine Arnold Theiler of Luzern was. Max Theiler himself is born in Praetoria in 1899. He has been connected with Harvard University from 1922-1930, with the Rockefeller Foundation from 1930-1964. In 1964. he moved to Yale University. For his work in virology, especially on yellow fever he received the Nobelprice in 1950 .

Swiss-American Medical relations did, of course, (and do) not only run from East to West, but also from West to East. This holds particularly good for the period when many US medical students, who wanted a better education, went abroad as undergraduate or postgraduate students. Quite a few of them chose Sitzerland. Postgraduate students were particularly attracted through the fame of Swiss surgery and especially through the fame of Theodor Kocher. The most famous American pupil of Kocher (and his favorite) was undoubtedly Harvey W. Cushing (1869-1939), who came with his friends H.T. Jackson and J.B. Solly in 1900-1901 to Bern to work with Kocher and Kronecker. Before him, the famous Hopkins pharmacologist J.J.Abel and McFaden had done postgraduate studies in Bern. Dermatologists like Sulzberger were attracted by Bruno Bloch in Zurich.

The mass of the American undergraduate students went to Zurich. Between 1870 and 1910120 Americans studied there medicine. Two thirds of them came from the North American East Cost. Bern had only 13 and Basel only 10 American medical undergraduate students during this period. In exchange Basel can claim to have had two American professors, Hanson Kelly Corning (1861-1951), the wellknown anatomist, and the pharmacologist Edwin Stanton Faust (1870-1928).

Women constituted in the 19 th century a large contingent of the American student population in Switzerland, as at that time the study of medi- 
cine was almost inaccessible to women in the US. 57 out of the 120 Americans studying in Zurich from 1870-1910 were women. Especially well remembered of these Zurich girls are Susan Dimock (1847-1875) later a Boston gynaecologist and Mary Smith, who graduated in Zurich in 1880 and became a wellknown surgeon in the US. Of the American girl students in Bern Caroline Davis, Anne Kriemont or Ida Hoff are still remembered.

After the first World War the problem of American medical undergraduate students in Switzerland had changed. The US could now offer a perfectly adequate medical education to its youth and began even already to attract foreigners for postgraduate studies. American students who till very recently came still in numbers to Switzerland, came now rather because they could not find a place in US schools on account of their poor scholastic record or their race or religion. The stream of US postgraduate students has also thinned out, though there are still some working here and there e.g. in brain research, medical history, psychiatry, or neuro-surgery.

A special chapter in American-Swiss medical relations is that of the education of Swiss students of dentistry in the US. It is well known that dentistry reached in the US a scientific level long before it did so in Europe. Therefore ambitious European students of dentistry went often to America, studied there and took an American degree. It is significant that $5 \%$ of the Swiss dentists practising between 1890-1960 had graduated in the U S A. In 1897 US graduates founded the American Dental Association of Switzerland. Such outstanding fathers of the Zurich Dental School like A.Gysi (1865-1957) or G.A.Stoppany (1868-1945) were American trained. Furthermore other pioneers of dentistry in Switzerland like A.A.Steiger in Luzern, J.G. Vest in Basel, F. Egger in Berne, H. Berner in Aarau etc. etc. were US graduates. More on this phenomenon is to be found in the 1963 Zurich thesis of Rudolf Schwitzer: Das Studium der Schweizerischen Zahnärzte in den USA um die Jahrhundertwende.

We have in the foregoing only talked of the "officers" among physicians, but there were also hundreds of "infantry men" which we could not mention. There were e.g. men like Sam Nickles (1839-1908) of Cincinnati, the child of Bernese parents, who left no spectacular accomplishments, but was such a good professor that he is still talked of in the place where he once worked!

It were as a matter of fact just as much these "infantry men", the hundreds of more or less anonymous emigrants to the US or US students in Switzerland, who in their lowly and modest way spread Swiss respectively 
American influence in the respective countries. And we cannot close this survey without remembering them gratefully.

\section{Bibliography for Swiss-US medical relations}

Ackerknecht E.H., Grands médecins suisses 1500-1900, Paris 1966.

Buess H., Heinrich Banga 1848-1913, Schweiz. Med. Wschr. 78 (1948) 240.

Bonner Th. N., American doctors and German universities, Lincoln 1963.

Feierstein S., Adolf Meyer, Zürich 1965.

Fischer H., Carl Voegtlin, Bull. Schweiz. Ak. Med. Wiss. 16, 323-26.

Fulton John, Harvey Cushing, Springfield 1946.

Grüning John Paul von, The Swiss in the US, Madison (Wis.) 1940.

Kelly H. A. and Burrage W. L., Dictionary of American medical biography, New York 1928.

Lётт A., Schweizer im Ausland, Genf 1931.

MeIER H.K., The US and Switzerland in the 19th century, The Hague 1965.

Prominent Americans of Swiss origin, New York 1932.

Röthlin O.M., Edwin Klebs (1834-1913), Zürich 1962.

Schwitzer R., Das Studium der Schweizerischen Zahnärzte in den U SA, Zürich 1963.

UHL F., Amerikanische Medizin von Europäern beurteilt, Zürich 1959.

Die vorausgehenden Vorträge von Erna Lesky (Wien), George Petit und J. Théodoridès (Banyuls-sur-Mer und Paris), Luigi Belloni (Milano), Gerhart Rudolph(Kiel), S.S.B.Gilder (London) und E. H. Ackerknecht (Zürich), der letztere als Dr.-Markus-Guggenheim-Vortrag des Jahres 1971, wurden an der Jubiläumstagung zum 50 jährigen Bestehen der Schweizerischen Gesellschaft für Geschichte der Medizin und der Naturwissenschaften am 9. Oktober 1971 an der Festsitzung der Gesellschaft in Fribourg (Schweiz) gehalten.

Allen Rednern danken wir für ihre wertvollen Beiträge und für ihre freundschaftliche Gesinnung. 